\title{
LH receptors in ovine corpora lutea in relation to various physiological states and effects PGF- $2 \alpha$ on LH-induced steroidogenesis in vitro
}

\author{
M. Evrard-Herouard, M. P. de la Llosa-Hermier, J. Martinet*, \\ P. Mauleon $\dagger$, P. de la Llosa and C. Hermier \\ C.N.R.S. G.R.34-Laboratoire des Hormones Polypeptidiques, 91190 Gif-sur-Yvette; \\ *I.N.R.A.—Laboratoire Physiologie de la Lactation, 78350 Jouy-en-Josas, and \\ $\dagger$ †.N.R.A.-Station de Physiologie de la Reproduction, 37380 Nouzilly, France
}

\begin{abstract}
Summary. The LH binding properties (determined using tritiated methylated $\mathrm{LH}$ ) and the in-vitro steroidogenic activity of $\mathrm{CL}$ from ewes in the oestrous cycle or early pregnancy (Day 18) were compared.

No significant alteration in the $K_{\mathrm{d}}$ values was observed. However, the number of sites was maximal at Day 10 of the cycle and in early pregnant animals which had not been pregnant for at least 3 months (dry ewes). Non-lactating or suckling ewes had half the numbers of binding sites. The increase of the number of receptor sites was accompanied by a steroidogenic response at lower LH concentration.

During incubation or superfusion for $5 \mathrm{~h}$, a refractoriness to $\mathrm{LH}$ stimulation appeared after $1 \mathrm{~h}$ with high $\mathrm{LH}$ concentrations and after $3 \mathrm{~h}$ with low concentrations. The opposite effect of the addition of indomethacin or PGF-2 $\alpha$ suggests the intervention of PGs in this phenomenon.
\end{abstract}

\section{Introduction}

The first step in the action of LH on its target organ is the binding of the hormone to the cell membrane receptors. This binding is dependent upon the concentration of $\mathrm{LH}$ and the concentration of LH receptors. The subsequent steroidogenic effect may differ according to the hormonal environment of the ovaries.

LH has a luteotrophic effect in vivo (Alloiteau \& Mayer, 1967) but in sheep LH alone is unable to maintain this function without the co-operation of prolactin (Denamur, Martinet \& Short, 1973). In corpora lutea of early pregnancy, progesterone secretion differs according to the physiological siatie of the ewe; it is specially low in suckling ewes (Cognié, Hernandez-Barrreto \& Saumande, 1975).

Steroidogenic activity in vitro can be studied by incubation or by superfusion techniques using various tissues. Hermier \& Jutisz (1968) have shown, using incubation techniques, that there is a correlation between LH concentration in the medium and progesterone synthesis in the ovaries of pseudopregnant rats. The addition of prolactin increases the response to LH stimulation (Watson, 1971), but the time course of the response differs according to the concentration of LH (Hermier, de la Llosa-Hermier, Evrard \& de la Llosa, 1978). The present study is on the sensitivity of the steroidogenic response to $\mathrm{LH}$, its variation in relation to different physiological phases and the corresponding changes observed in LH receptors. Since a decrease 
in progesterone release is observed in vitro after $\mathrm{LH}$ stimulation for several hours the possible role of prostaglandin (PG) F-2 $\alpha$ has also been investigated.

The catabolism of progesterone to $20 \alpha$-dihydroprogesterone during the superfusion experiments has also been studied because PGF- $2 \alpha$ has a stimulatory action on this reaction which contrasts with the inhibitory effect of prolactin (de la Llosa-Hermier, Leboulleux, Evrard \& Hermier, 1979).

\section{Materials and Methods}

\section{Hormones and drugs}

Highly purified $\mathrm{LH}_{-} \mathrm{M}_{4}(2 \times \mathrm{NIH}-\mathrm{LH}-\mathrm{S} 11)$ was obtained in one of our laboratories (C.N.R.S.-GR 34) by the method of Jutisz \& Courte (1968). Labelling of ovine LH with tritium was achieved by reductive methylation (de la Llosa, Marche, Morgat \& de la Llosa-Hermier, 1974) and the tritiated methylated LH was purified by gel chromatography on Biogel P100. The solution of ${ }^{3} \mathrm{H}$-labelled $\mathrm{LH}$ (sp. act. $20 \mathrm{Ci} / \mathrm{mmol}$ ) was stored in liquid nitrogen and used within 4 months. During this time, $100 \%$ of the biological activity was preserved.

Prostaglandin F-2a $(5 \mathrm{mg} / \mathrm{ml}$ in ethanol) was generously supplied by Dr J. Pike (Upjohn Company, Kalamazoo, Michigan, U.S.A.). Indomethacin (an inhibitor of prostaglandin synthesis) was obtained from Merck-Sharp and Dohme (Rahway, New-Jersey, U.S.A.). $\left[{ }^{3} \mathrm{H} \mid\right.$ Progesterone (sp. act. $114 \mathrm{Ci}$-mmol) and $\left[{ }^{3} \mathrm{H} \mid 20 \alpha\right.$-dihydroprogesterone (sp. act. 56 $\mathrm{Ci} / \mathrm{mmol}$ ) were purchased from New England Nuclear (Boston, Massachusetts, U.S.A.).

\section{Animals}

Ewes of the Prealpes du Sud breed used for the studies of corpora lutea of the cycle were 3 years of age. The luteal tissue was collected surgically from ovaries on Days 3, 6, 10, 14 of the oestrous cycle during the breeding season (August to January). Day 0 was the day of oestrous behaviour of the ewe which was checked twice a day with an aproned ram.

Ile-de-France ewes, 3-6 years old, were used to study corpora lutea during pregnancy. Ovulation was obtained during anoestrus by vaginal administration of fluorogestone acetate (Searle, France) and an i.m. injection of 500 i.u. PMSG (Organon). Three types of ewes were studied: (1) suckling animals with 1 lamb; (2) dry ewes which had not been pregnant during the 3 previous months; and (3) non-lactating ewes whose lambs had been removed within the first 2 days of lambing. In the ewes of Groups 1 and 3, a 28-day interval was preserved between lambing and hormone treatment and a 40-day interval between lambing and artificial insemination. These animals were killed on the 18th day of pregnancy (checked by blastocyst recovery following perfusion of the genital tract) and the corpora lutea were removed. Several corpora lutea were pooled to provide the amount of tissue necessary for binding experiments.

\section{Binding studies}

Scatchard analysis (1949) was performed on data obtained using the method described by de la Llosa-Hermier, Hermier \& de la Llosa (1976). The pooled corpora lutea were minced and

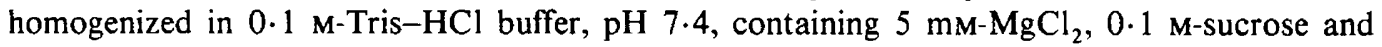
$0 \cdot 1 \%$ bovine serum albumin. Briefly, aliquots of the homogenate $(100-200 \mathrm{mg}$ luteal tissue $/ 2 \mathrm{ml}$ buffer) were incubated for $30 \mathrm{~min}$ (necessary time to reach equilibrium) at $37^{\circ} \mathrm{C}$ in the presence of different amounts of ${ }^{3} \mathrm{H}$-labelled $\mathrm{LH}(0.5-5 \mathrm{ng} / \mathrm{ml})$. Bound hormone was separated from unbound hormone by centrifugation at $6000 \mathrm{~g}$ for $15 \mathrm{~min}$ at $0^{\circ} \mathrm{C}$ and and the supernatant was discarded. The pellet was washed in assay-buffer and solubilized with $1 \mathrm{ml}$ soluene (Packard). Radioactivity was determined in a Packard tri-carb scintillation spectrometer using dimilume 
(Packard). Unspecific binding (about 20\%) was deducted. Protein was determined according to the method of Lowry, Rosebrough, Farr \& Randall (1951).

\section{Progesterone synthesis studies}

Incubation. Several corpora lutea from the same ewe were sliced and pooled before distribution in incubation flasks. Incubation was carried out for $3 \mathrm{~h}$ in a metabolic shaker at $37^{\circ} \mathrm{C}$ in $10 \mathrm{ml} \mathrm{Krebs-Ringer} \mathrm{bicarbonate} \mathrm{buffer} \mathrm{(Umbreit,} \mathrm{Burris} \mathrm{\&} \mathrm{Stauffer,} \mathrm{1964)} \mathrm{saturated}$ with $95 \% \mathrm{O}_{2}-5 \% \mathrm{CO}_{2}$. Glucose $(2 \mathrm{mg} / \mathrm{ml})$ and bovine serum albumin $(0.5 \%)$ were added to the buffer solution. After incubation the tissue was discarded from the medium and homogenized in fresh Krebs-Ringer. The flasks were kept frozen until steroid analysis.

Superfusion. Isolated and minced corpora lutea were placed in an apparatus similar to that described by Hashimoto, Asano \& Wiest (1975). A tissue chamber (10 ml) immersed in an

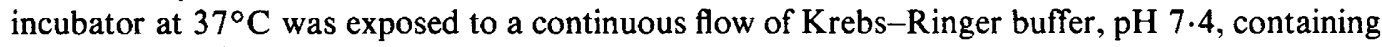
glucose $(2 \mathrm{mg} / \mathrm{ml})$ and bovine serum albumin $(0.5 \%)$. This medium was continuously saturated with a mixture of $95 \% \mathrm{O}_{2}-5 \% \mathrm{CO}_{2}$ and pumped through the chamber at a constant flow rate of $10 \mathrm{ml} / \mathrm{h}$ using a peristaltic pump (Gilson). The effluent buffer was collected in 10-ml fractions over a period of $5 \mathrm{~h}$.

Radioimmunoassay of steroids. Progesterone and $20 \alpha$-dihydroprogesterone were measured after extraction with petroleum ether. The solvent was evaporated at a temperature of $40^{\circ} \mathrm{C}$ and the residue resuspended in $0.1 \%$ gelatin- $0.1 \mathrm{M}$-phosphate buffered to $\mathrm{pH} 7 \cdot 4$. A volume of $0 \cdot 1$ $\mathrm{ml}$ of this suspension, or steroid standard solutions, was placed in polypropylene test tubes together with $0.1 \mathrm{ml}\left[{ }^{3} \mathrm{H}\right]$ progesterone $\left(2000\right.$ c.p.m.) or $\left[{ }^{3} \mathrm{H}\right] 20 \alpha$-dihydroprogesterone $(2000$ c.p.m.) and $0.1 \mathrm{ml}$ of the corresponding diluted (1:20000) antiserum (Institut Pasteur, Paris). The mean association constants of antisera were, according to the supplier, $1.3 \times 10^{10} \mathrm{M}^{-1}$ for progesterone and $3.9 \times 10^{9} \mathrm{M}^{-1}$ for $20 \alpha$-dihydroprogesterone. The only steroids showing a cross-reaction with the progesterone and $20 \alpha$-dihydroprogesterone antisera were respectively desoxycorticosterone (3\%) and 20ß-dihydroprogesterone $(6 \%)$. The tubes were vortexed and allowed to equilibrate for $30 \mathrm{~min}$ at room temperature, followed by at least $15 \mathrm{~min}$ at $0^{\circ} \mathrm{C}$. Within $1 \mathrm{~min}, 1 \mathrm{ml}$ dextran-charcoal solution was added to all the tubes, which were centrifuged $10 \mathrm{~min}$ later at $2200 \mathrm{~g}$ for $5 \mathrm{~min}$. The supernatant liquid was decanted into a scintillation vial and scintillation mixture was added for radioactivity determination. Non-specific binding of the radioimmunoassay was $<4 \%$. The volume of medium extracted was chosen so that the samples could be analysed at two dose levels between the 25 and $75 \%$ inhibition points of the standard calibration curve. The $50 \%$ inhibition level on this curve occurred at a dose of $59 \pm 2 \mathrm{pg}$. Procedural losses were monitored by addition of ${ }^{3} \mathrm{H}$-labelled steroid and calculated on the basis of the subsequent recovery of this added radioactivity.

\section{Results}

\section{Binding of ${ }^{3} \mathrm{H}$-labelled $\mathrm{LH}$ to different types of corpora lutea}

The apparent dissociation constant and the number of sites was calculated using the Scatchard (1949) analysis. The $K_{\mathrm{d}}$ values corresponding to the receptors with greater affinity for the hormone for the different types of corpora lutea studied are shown in Table 1: none of the differences was significant. A maximum number of sites was found in luteal tissue at Days 9-10 of the cycle and in that of Group 2 pregnant ewes.

\section{Progesterone synthesis bv corpora lutea}

As shown in Table 2, the luteal tissue of Group 2 ewes responded to very low concentrations of LH. Greater concentrations were needed to induce maximal secretion by luteal tissue of 
Table 1. LH binding capacity and apparent dissociation constants in corpora lutea of ewes

\begin{tabular}{lccc}
\hline \multicolumn{1}{c}{ Tissue } & $\begin{array}{c}\text { No. of } \\
\text { determinations }\end{array}$ & $K_{\mathrm{d}}\left(10^{-10} \mathrm{M}\right)$ & $\begin{array}{c}\text { Binding capacity } \\
(\mathrm{pg} / \mathrm{mg} \text { protein })\end{array}$ \\
\hline Cyclic ewes & & & \\
3-4 days & 2 & $0 \cdot 5 ; 3 \cdot 1$ & $37 ; 67$ \\
6-7 days & 2 & $0 \cdot 5 ; 2 \cdot 9$ & $70 ; 102$ \\
9-10 days & 3 & $2 \cdot 3 \pm 1 \cdot 1$ & $131 \pm 18^{*}$ \\
14 days & 2 & $0 \cdot 8 ; 2 \cdot 0$ & $40 ; 90$ \\
\hline Pregnant ewes & & & \\
(1) Suckling & 4 & $1 \cdot 3 \pm 0 \cdot 5$ & $79 \pm 12$ \\
(2) Dry & 3 & $0.9 \pm 0 \cdot 2$ & $193 \pm 6 \dagger$ \\
(3) Non-lactating & 3 & $1 \cdot 2 \pm 0.2$ & $87 \pm 7$ \\
\hline
\end{tabular}

\footnotetext{
Values are mean \pm s.e.m.

* Significantly higher than other values for cyclic ewes, $P<0.05$ (Student's $t$ test).

† Significantly higher than other values for pregnant ewes, $P<0.001$ (Student's $t$ test).
}

Group 3 ewes, and there was no stimulation of progesterone in the medium for incubations of tissue from Group 1 ewes, although there was an increase in tissue concentrations. In superfusion experiments (Text-figs 1 and 2), the amount of progesterone released into the medium by luteal tissue from Group 2 ewes was higher $(29.0 \pm 3.6 \mu \mathrm{g} / \mathrm{g}$ tissue) than that by luteal tissue from cyclic ewes $\left(14 \pm 1 \mu \mathrm{g} / \mathrm{g}\right.$ ), the $\mathrm{LH}$ concentration being $5 \times 10^{-9} \mathrm{M}$ in both cases. There was no difference between the amount of progesterone present in the luteal tissues of the two types of ewes.

A comparison of the results reported above for the binding experiments (Table 1) and for the steroidogenic response (Table 2, Text-figs 1 and 2) showed that the number of sites and tissue secretory activity changed in the same manner.

Table 2. LH-stimulated progesterone synthesis ( $\mu \mathrm{g} / \mathrm{g}$ tissue) by corpora lutea of pregnant ewes

\begin{tabular}{|c|c|c|c|c|c|c|}
\hline \multirow{2}{*}{$\begin{array}{l}\text { LH conc. } \\
\text { (M) }\end{array}$} & \multicolumn{2}{|c|}{$\begin{array}{l}\text { Group 1 } \\
\text { (suckling) }\end{array}$} & \multicolumn{2}{|c|}{$\begin{array}{l}\text { Group } 2 \\
\text { (dry) }\end{array}$} & \multicolumn{2}{|c|}{$\begin{array}{c}\text { Group } 3 \\
\text { (non-lactating) }\end{array}$} \\
\hline & Medium & Tissue & Medium & Tissue & Medium & Tissue \\
\hline 0 (control) & $38 \cdot 4 \pm 1 \cdot 3$ & $24 \cdot 3 \pm 1 \cdot 4$ & $173 \cdot 5 \pm 11 \cdot 0$ & $122.6 \pm 3.6$ & $53 \cdot 4 \pm 2 \cdot 2$ & $39 \cdot 8 \pm 1 \cdot 0$ \\
\hline $1.7 \times 10^{-9}$ & & & $201 \cdot 0 \pm 8.6$ & $157.7 \pm 5.6 \dagger$ & $57.8 \pm 1.4$ & $46.0 \pm 2.5 \dagger$ \\
\hline $5.0 \times 10^{-9}$ & & & $239.9 \pm 9.2 \dagger$ & $176.6 \pm 16.0^{*}$ & $49 \cdot 5 \pm 3 \cdot 5$ & $44.9 \pm 0.8 \dagger$ \\
\hline $1.0 \times 10^{-8}$ & & & $184.7 \pm 3.4$ & $167.0 \pm 6.0 \dagger$ & & \\
\hline $1.5 \times 10^{-8}$ & $35 \cdot 2 \pm 0.6$ & $24.0 \pm 1.6$ & & & $86 \cdot 1 \pm 4.7 \dagger$ & $59.9 \pm 0.8 \dagger$ \\
\hline $2.0 \times 10^{-8}$ & & & $174 \cdot 3 \pm 10 \cdot 7$ & $173.7 \pm 4.3 \dagger$ & & \\
\hline $2.5 \times 10^{-8}$ & $38 \cdot 3 \pm 4 \cdot 2$ & $42.3 \pm 1.9 \dagger$ & & & $62 \cdot 0 \pm 3 \cdot 9^{*}$ & $60 \cdot 1 \pm 2.7 \dagger$ \\
\hline $4.0 \times 10^{-8}$ & & & $170 \cdot 0 \pm 5 \cdot 3$ & $139 \cdot 0 \pm 3 \cdot 7^{*}$ & & \\
\hline $8.0 \times 10^{-8}$ & $39 \cdot 2 \pm 2 \cdot 5$ & $35 \cdot 1 \pm 3 \cdot 0^{*}$ & & & $83.9 \pm 2.9 \dagger$ & $78 \cdot 1 \pm 4.3 \dagger$ \\
\hline $2.4 \times 10^{-7}$ & $15.0 \pm 0.8+$ & $32 \cdot 6 \pm 2 \cdot 3^{*}$ & & & & \\
\hline
\end{tabular}

Incubations were carried out for $3 \mathrm{~h}$.

Each value represents the mean \pm s.e.m. for 4 observations.

Significantly different from control value, ${ }^{*} P<0.05 ; \dagger P<0.01$.

\section{Time course of progesterone synthesis}

A superfusion technique was employed for the study of progesterone synthesis over $5 \mathrm{~h}$ (Text-fig. 1). At an LH concentration of $5 \times 10^{-9} \mathrm{M}$, the progesterone concentration in the medium increased progressively between 0 and $2 \mathrm{~h}$ and then decreased, suggesting a 
refractoriness of the tissue to $\mathrm{LH}$ stimulation. A similar time course was obtained with an LH concentration of $1 \times 10^{-8} \mathrm{M}$. At higher concentrations $\left(2 \times 10^{-8} \mathrm{M}, 8 \times 10^{-8} \mathrm{M}\right)$ no release of progesterone was found. A refractoriness appeared within $1 \mathrm{~h}$. Increasing the LH concentration above $5 \times 10^{-9} \mathrm{M}$ diminished the progesterone accumulation in the tissue (Text-fig. 1).
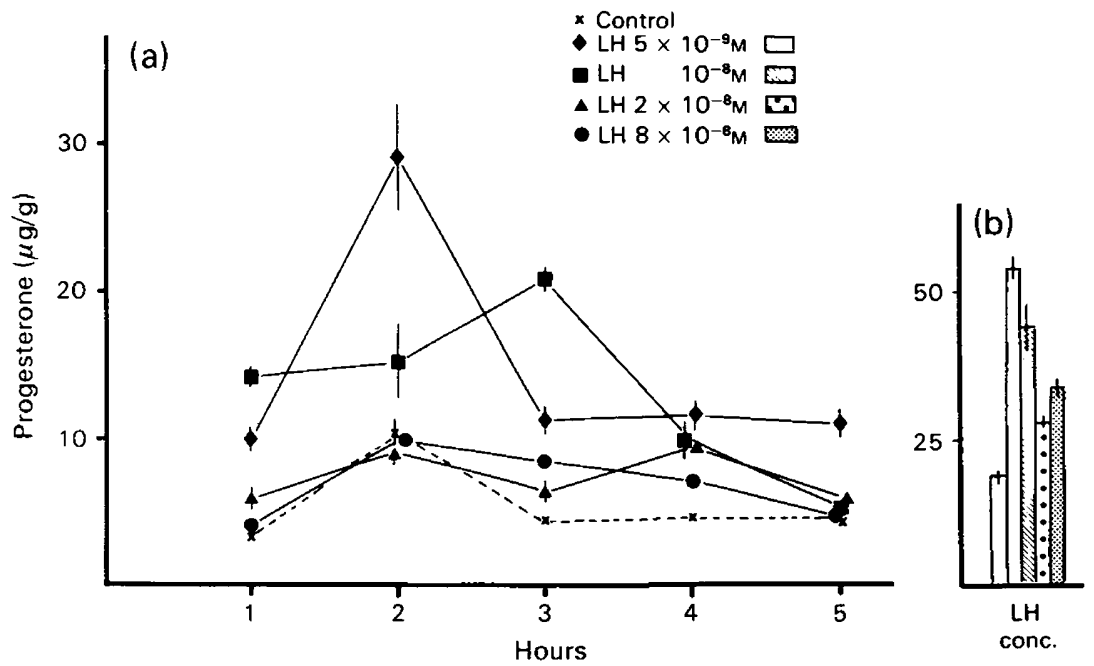

Text-fig. 1. Time course of (a) release of progesterone into the medium and (b) tissue concentrations of progesterone after superfusion for $5 \mathrm{~h}$ of about $100 \mathrm{mg}$ of minced corpora lutea from Day-18 pregnant ewes (Group 2, dry) in $10 \mathrm{ml} \mathrm{Krebs-Ringer-bicarbonate} \mathrm{buffer} \mathrm{(10}$ $\mathrm{ml} / \mathrm{h}$ ). Values are mean \pm s.e.m. for 4 observations.

The 20a-dihydroprogesterone accumulated in the tissue or released was measured in the superfusion experiments. As shown in Table 3, this steroid appeared in the medium only after superfusion for $2 \mathrm{~h}$ at the higher $\mathrm{LH}$ concentration and for $5 \mathrm{~h}$ at the lower $\mathrm{LH}$ concentration. But during this time, progesterone release declined. The accumulation of $20 \alpha$-dihydroprogesterone in the tissue (Table 3) was significantly stimulated only at $2 \times 10^{-8} \mathrm{M} \mathrm{LH}$, whereas progesterone accumulation was negligible. Therefore in both the medium and in the tissue the rise of 20a-dihydroprogesterone corresponded with a decrease in progesterone concentration. Nevertheless, the amount of $20 \alpha$-dihydroprogesterone observed in the medium or in the tissue was only about $1 / 10$ that of progesterone.

Table 3. LH-stimulated synthesis of $20 a$-dihydroprogesterone by corpora lutea of early pregnant ewes (dry)

\begin{tabular}{|c|c|c|c|}
\hline \multirow{2}{*}{$\begin{array}{l}\text { LH conc. } \\
\text { (M) }\end{array}$} & \multicolumn{2}{|c|}{$\begin{array}{l}\text { Steroid in medium } \\
\text { (ng/g tissue) }\end{array}$} & \multirow{2}{*}{$\frac{\begin{array}{c}\text { Steroid in tissue } \\
\text { (ng/g tissue) }\end{array}}{5 \mathrm{~h}}$} \\
\hline & $2 \mathrm{~h}$ & $5 \mathrm{~h}$ & \\
\hline 0 (control) & $0.684 \pm 0.065$ & $1.856 \pm 0.230$ & $0.855 \pm 0.124$ \\
\hline $5 \times 10^{-9}$ & $0.420 \pm 0.092$ & $2.935 \pm 0.218^{*}$ & $0.615 \pm 0.050$ \\
\hline $2 \times 10^{-8}$ & $3.649 \pm 0.557^{*}$ & $3.545 \pm 0.378 t$ & $1.362 \pm 0.072^{*}$ \\
\hline
\end{tabular}

Superfusion was carried out for $5 \mathrm{~h}$.

Each value represents the mean \pm s.e.m. for 4 observations.

Significantly higher than control value. ${ }^{*} P<0.05: \dagger P<0.01$. 


\section{Role of $P G F-2 \alpha$}

Effect on LH-stimulated progesterone synthesis. Corpora lutea of ewes at Days 9-10 of the cycle were minced and 3 samples ( $100 \mathrm{mg}$ tissue/sample) were superfused for $5 \mathrm{~h}$. One sample served as control, the second received LH $\left(5 \times 10^{-9} \mathrm{M}\right)$ and the third received both $\mathrm{LH}\left(5 \times 10^{-9}\right.$ M) and PGF-2 $\alpha\left(7 \times 10^{-7} \mathrm{M}\right)$ solubilized in Krebs-Ringer-bicarbonate. The time course of progesterone release is illustrated in Text-fig. $2(\mathrm{a}, \mathrm{b})$. At the end of the superfusion period the amount of steroid in the tissue was lower in the sample treated with PGF-2a.

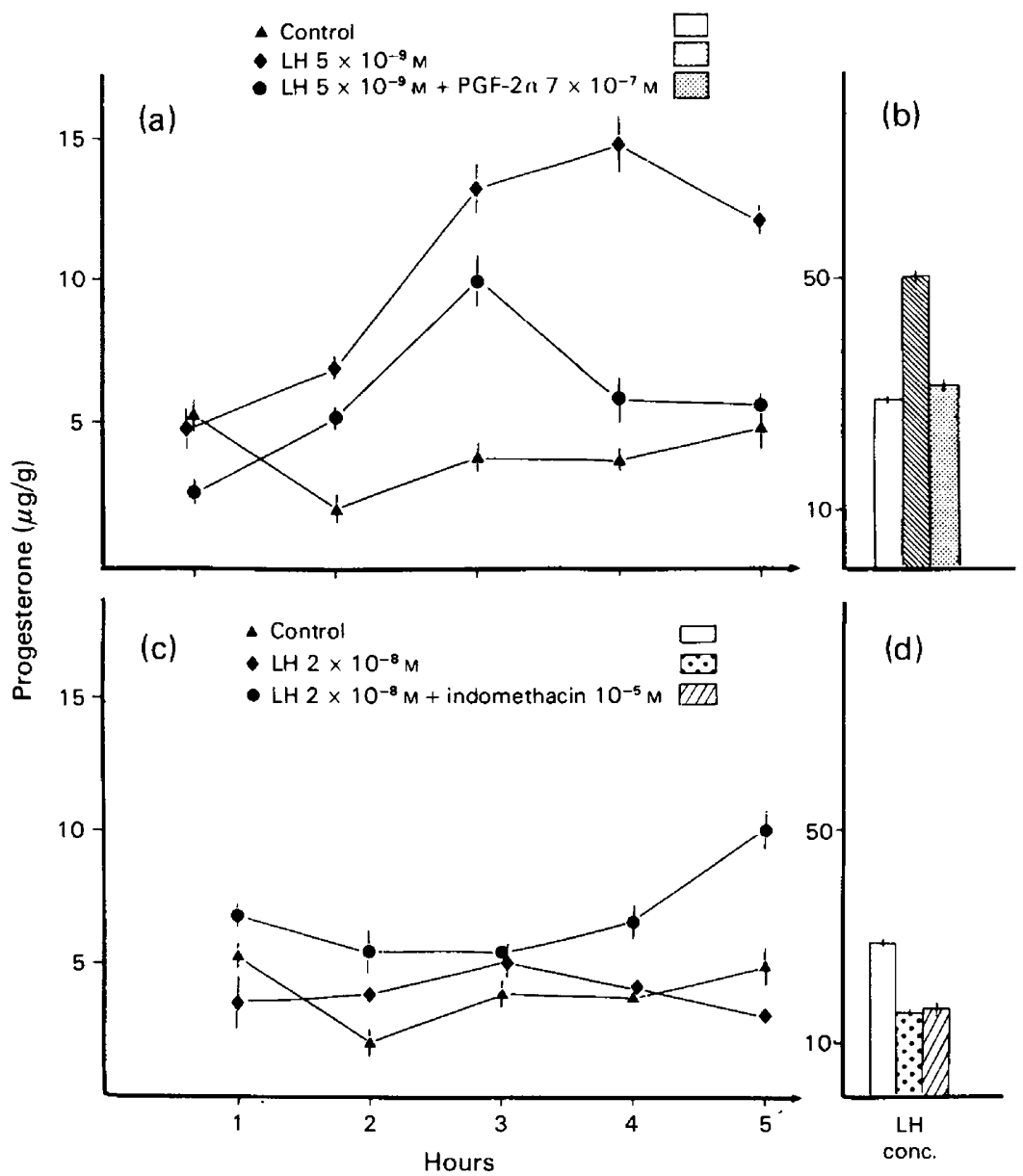

Text-fig. 2. Time course of $(a, c)$ release of progesterone into the medium and (b. d) tissue concentrations of progesterone in the luteal tissue of cyclic ewes (Day 10) superfused for $5 \mathrm{~h}$ in the presence of LH and (a,b) PGF-2 $\alpha$ or $(c, d)$ indomethacin. Values are mean \pm s.e.m. for 4 observations.

Effect of indomethacin. Corpora lutea were removed on the 10th day of the cycle and minced. Three samples $(100 \mathrm{mg})$ were preincubated for $30 \mathrm{~min}$, only the third in the presence of $10^{-5} \mathrm{M}$-indomethacin. Indomethacin was first dissolved in ethanol and $5 \mu \mathrm{l}$ of this solution was added to the medium $(5 \mathrm{ml})$ at the pre-incubation stage. Then, samples were superfused for $5 \mathrm{~h}$. The first sample was used as control, the second received LH at $2 \times 10^{-8} \mathrm{M}$ (a concentration which does not stimulate the synthesis of progesterone in these superfusion experiments, see Text-fig. 1), and the third sample received both $\mathrm{LH}\left(2 \times 10^{-8} \mathrm{M}\right)$ and indomethacin $\left(10^{-5} \mathrm{M}\right)$. The 
results are shown in Text-fig. 2 (c, d). The amount of progesterone was significantly increased in the medium but not in the tissue. This suggests that. since indomethacin inhibits the synthesis of endogenous prostaglandin in luteal tissue stimulated by LH, it acted in these experiments by suppressing the negative effect of prostaglandin on the synthesis of progesterone.

\section{Discussion}

The results reported in this paper show that the $K_{\mathrm{d}}$ values of the binding of LH to corpora lutea receptors are not changed throughout the cycle or in the different physiological states studied in the ewe although the number of sites is modified.

Thanki \& Steinberger (1976), who used iodinated human LH to study the receptors of rat testes at different ages, did not observe any significant change in the $K_{\mathrm{d}}$ value. Stouffer. Tyrey \& Schomberg (1976), using iodinated hCG, also failed to find changes in the $K_{\mathrm{d}}$ value during the growth of porcine granulosa cells. A modification of the number of sites throughout the human cycle has been reported by Wardlaw, Lauersen \& Saxena (1975), who used iodinated hCG as radioligand. With the same radioligand. Dieckman. O'Callaghan, Nett \& Niswender (1978) found a maximum number of luteal LH sites on the 10th day of the cycle. Our results using tritiated LH confirm this observation.

In our experiments the increase in the number of receptor sites was accompanied by a greater sensitivity of the tissue to LH. Purvis, Clausen \& Hansson (1978) reported similar results for feminized testicular tissue treated with iodinated hLH.

An increased tissue progesterone concentration after $\mathrm{LH}$ treatment but no release of the steroid into the medium was observed only for luteal tissue from suckling ewes in our experiments, but we have no explanation for this anomaly.

During the times studied, a refractoriness to LH stimulation appeared. This refractoriness was evident after $3 \mathrm{~h}$ with $\mathrm{LH}$ concentration of about $5 \times 10^{-9} \mathrm{M}$, but was clearly apparent after $1 \mathrm{~h}$ if higher $\mathrm{LH}$ concentrations were used $\left(2 \times 10^{-8} \mathrm{M}\right)$. Other authors have reported a similar phenomenon in vitro after $6 \mathrm{~h}$ of incubation with high hCG concentrations: refractoriness seems to be associated with a loss of receptors and desensitization of adenylate cyclase even though steroidogenesis can still sometimes be stimulated (ovary: Bockaert, Hunzicker-Dunn \& Birnbaumer, 1976; Conti, Harwood, Dufau \& Catt, 1977; Stouffer, Nixon \& Hodgen, 1978; testis: Hsueh, Dufau \& Catt, 1977; adrenal gland: Morera, Cathiard \& Saez, 1978). Our results were obtained during treatment with ovine LH (and not hCG which could be considered as an 'analogue' of the physiological hormone of the ewe). Since the addition of indomethacin to the medium increased the $\mathrm{LH}$-induced release of progesterone after $3 \mathrm{~h}$ of superfusion, it may be concluded that the cells are still able to respond to LH by synthesizing progesterone. A prolonged action can also induce a depletion of precursors or of stored product, thus reducing the rate of progesterone synthesis. But the release of the $\mathrm{LH}$-induced progesterone secretion observed here after an intense stimulation by a high concentration of LH in the medium argues against this explanation (precursor deficiency).

Some published data suggest that endogenous luteal prostaglandins could be involved in the refractoriness induced by LH treatment. Demers, Behrman \& Greep (1973) reported that the synthesis of prostaglandins in rat $\mathrm{CL}$ is stimulated by $\mathrm{LH}$, and Grinwich, Hichens \& Behrman (1976) have shown that treatment with PGF-2 $\alpha$ in vivo causes a decrease in the number of LH receptors in the rat. But the decrease in the concentration of progesterone in plasma is clearly observed after $2 \mathrm{~h}$ whereas the decline in the numbers of receptors induced by PGF- $2 \alpha$ can only be detected $6 \mathrm{~h}$ after the injection in vivo. Thus, in these experiments the decrease in circulating progesterone does not seem to be preceded by a decrease in receptor numbers. We have previously investigated the action of PGF- $2 \alpha$ in the events following the binding of the hormone to the receptors, especially its influence on $20 \alpha$-hydroxysteroid dehydrogenase activity. This 
activity is stimulated by PG, but the amount of $20 \alpha$-dihydroprogesterone found in the tissue, which may be increased as a result of the action of this enzyme on progesterone, is too low to afford an explanation of the total decrease in progesterone synthesis by ovine corpora lutea even if it contributes to this decrease. For rat corpora lutea. however. a good correlation between the increase of $20 \alpha$-dihydroprogesterone and the concomitant decrease of progesterone was shown by Torjesen \& Aakvaag (1977).

Our results suggest that prostaglandins could be an element in the intracellular modulation of progesterone synthesis in ovine corpora lutea as in rat ovaries (Evrard, Leboulleux \& Hermier, 1978 ) and could act as a factor regulating this synthesis when the action of the hormone is particularly intense or prolonged.

We thank Mrs P. Leboulleux for her excellent technical assistance: Mrs M. Massoud for surgical assistance: Mr Poissonier, for preparation of the ovine LH and Dr J. Williams for help with the manuscript. This work was supported in part by a grant of the Foundation for Hormone Research.

\section{References}

Alloiteau, J.J. \& Mayer, G. (1967) Problèmes concernant la formation, le maintien et la régression des corps jaunes chez le rat. Archs Anat. microsc. Morph. exp. 56. 191-198.

Bockaert, J., Hunzicker-Dunn, M. \& Birnbaumer, L. (1976) Hormone-stimulated desensitization of hormone-dependent adenyl cyclase. J. biol. Chem. 251. 2653-2663.

Cognié, Y., Hernandez-Barreto, M. \& Saumande, J. (1975) Fertility in nursing ewes during the nonbreeding season. Annls Biol. anim. Biochim. Biophy's. 15. 329-343.

Conti, M., Harwood, J.P., Dufau, M.L. \& Catt, K.J. (1977) Regulation of luteinizing hormone receptors and adenylate cyclase activity by gonadotrophin in the rat ovary. Mol. Pharmac. 13, 1024-1032.

de la Llosa, P., Marche, P., Morgat, J.L. \& de la Llosa-Hermier, M.P. (1974) A new procedure for labelling luteinizing hormone with tritium. FEBS Letters 45, 162-165.

de la Llosa-Hermier, M.P., Hermier, C. \& de la Llosa, P. (1976) Binding of tritiated methylated luteinizing hormone to bovine corpus luteum receptors. Acta endocr., Copenh. 83, 393-401.

de la Llosa-Hermier, M.P., Leboulleux, P., Evrard, M. \& Hermier, C. (1979) In vitro effect of prolactin. prostaglandin $F_{2 u}$ and cycloheximide on $20 \alpha-$ dihydro-progesterone synthesis in pseudo-pregnant rat ovaries. J. Steroid Biochem. 10, 689-693.

Demers, L.M., Behrman, H.R. \& Greep, R.O. (1973) Effects of prostaglandins and gonadotropins on luteal prostaglandin and steroid biosynthesis. $A d v$. Biosci. 9. 701-707.

Denamur, R., Martinet, J. \& Short, R.V. (1973) Pituitary control of the ovine corpus luteum. J. Reprod. Fert. 32. 207-220.

Dieckman, M.A., O'Callaghan, P., Nett, T.M. \& Niswender, G.D. (1978) Validation of methods and quantification of luteal receptors for $\mathbf{L H}$ throughout the estrous cycle and early pregnancy in ewes. Biol. Reprod. 19, 999-1010.
Evrard, M., Leboulleux, P. \& Hermier, C. (1978) Role of prostaglandin $\mathrm{F}_{2 u}$ in modulation of $\mathrm{LH}$-stimulated steroidogenesis in vitro in different types of rat and ewe corpora lutea. Prostaglandins 16. 491-501.

Grinwich, D.L., Hichens, M. \& Behrman, H.R. (1976) Control of the LH receptor by prolactin and prostaglandin $\mathrm{F}_{2 \alpha}$ in rat corpora lutea. Biol. Reprod. 14. $212-218$.

Hashimoto, I., Asano, T. \& Wiest, W.G. (1975) Progestational function of perifused rat corpora lutea. Endocrinology 96. 421-430.

Hermier, C. \& Jutisz, M. (1968) Dosage de l'hormone luteinisante $(\mathrm{LH})$ fonde sur son action in vitro dans la biosynthèse de progestėrone. $C$. r. hebd. Séanc. Acad. Sci., Paris D 266, 242-245.

Hermier, C., de la Llosa-Hermier, M.P., Evrard, M. \& de la Llosa, P. (1978) Mechanism of action of the gonadotropic hormones in the stimulation of steroidogenesis. In Sexual Endocrinology, pp. 199229. Eds R. Vokaer \& R. de Maubeuge. Masson, Paris.

Hsueh, A.J.W., Dufau, M.L. \& Catt, K.J. (1977) Gonadotrophin induced regulation of luteinizing hormone receptors and desensitization of testicular $3^{\prime}: 5^{\prime}$-cyclic AMP and testosterone responses. Proc. natn. Acad. Sci. U.S.A. 74, 592-595.

Jutisz, M. \& Courte, C. (1968) Hormone lutéinisante (LH) de mouton. 1. Obtention à l'état apparemment homogène, ètude physico-chimique et biologique. Gen. comp. Endocr. 11, 562-574.

Lowry, O.H., Rosebrough, H.Y., Farr, A.L. \& Randall, R.J. (1951) Protein measurement with the Folin phenol reagent. J. biol. Chem. 193, 265-275.

Morera, A.M., Cathiard, A.M. \& Saez, J. (1978) ACTH induced refractoriness in cultured adrenal cell line $\left(\mathrm{Y}_{1}\right)$. Biochem. Biophys. Res. Commun. 83, 15531560.

Purvis, K., Clausen, O.P.F. \& Hansson, V. (1978) Decreased Leydig cell responsiveness in the testicular feminized male rat. Endocrinology 102, 10531060. 
Scatchard, G. (1949) The attractions of proteins for small molecules and ions. Ann. N.Y. Acad. Sci. 51 , 660-672.

Stouffer, R.L., Tyrey, L. \& Schomberg, D.W. (1976) Changes in ${ }^{125} \mathrm{I}$ labelled Human Chorionic Gonadotropin (hCG) binding to porcine granulosa cells during follicle development and cell culture. Endocrinology 99, 516-525.

Stouffer, R.L., Nixon, W.E. \& Hodgen, G.D. (1978) The refractory state of luteal cells isolated from rhesus monkeys after prolonged exposure to chorionic gonadotropin during early pregnancy. Biol. Reprod. 17, 858-864.

Thanki, H.K. \& Steinberger, A. (1976) ${ }^{125}$ I-LH binding to rat testes at various ages and posthypophysectomy. Endocr. Res. Commun. 3, 49-62.
Torjesen, P.A. \& Aakvaag, A. (1977) The serum levels

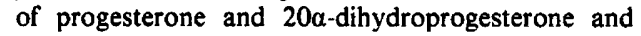
the ovarian LH, FSH and PRL binding during luteolysis of the superluteinized rat ovary. Acta endocr., Copenh. 86, 162-172.

Umbreit, W., Burris, R. \& Stauffer, J. (1964) Methods for preparation and study of tissues and enzymes. In Manometric techniques, pp. 114-158. Burgess. Minneapolis.

Wardlaw, S., Lauersen, N.H. \& Saxena, B.B. (1975) The LH-hCG receptor of human ovary at various stages of the menstrual cycle. Acta endocr., Copenh. 79, 568-576.

Watson, J. (1971) Progesterone synthesis in response to luteinizing hormone by rat ovarian tissue in vitro. $J$. Endocr. 49, 471-478.

Received 23 June 1980 